\title{
Pandita Ramabai: through her own words
}

Meera Kosambi (compiler/editor/translator) Oxford University Press, New Delhi, 2000, ISBN: 019-564-7548 ( $\mathrm{Hbk})$

Pandita Ramabai's name stands out as exemplary of women's participation in nationalist and colonial debates in late 19 th-century India. She remains an admirable figure who is remembered for breaking several caste, religious, and gender boundaries, for her work as a social reformer, for giving hope and refuge to many 'fallen' widows in 'Mukti Mission,' the home that she founded in 1889, for her great reputation as a Sanskrit scholar and poet, for her pioneering work in education, and for propagating the emancipation of women. Meera Kosambi's new compilation and translation of Ramabai's works, which includes previously unpublished writings retrieved from various international libraries, further restores the force of Ramabai's accomplishments and rediscovers her voice and contribution to the debates on nationalism, colonialism, and the politics of gender in the late 19th century. To this end, Kosambi provides a highly productive introduction, which functions at several levels. Overall, she summarizes the colonial and patriarchal contexts for the emergence of Ramabai's feminist consciousness, her conversion to Christianity, her personal aspirations and relationships, her international travels and education abroad, and her social contributions to the cause of Indian women at the expense of alienating mainstream Hindu society and some prominent social reformers. And in so doing, she also establishes the relevance of Ramabai's fight for gender equality to contemporary societies, globally.

While Kosambi's introduction firmly convinces the reader of the importance of Ramabai in contemporary feminist discourse, what is even more compelling is the intervention it makes in the singularly adulatory praise that Ramabai tends to receive. For, while offering the reader glimpses into why Ramabai deserves our admiration and scholarly recognition, she simultaneously exposes a personality fraught with contradictions. This becomes especially visible in Ramabai's complicated responses to upper-caste ideologies and the hypocrisy surrounding the treatment of Hindu women in the writings that follow the introduction. These reveal that despite her condemnation of Hindu patriarchal norms, Ramabai herself constructed rigid hierarchies of gender and class. Such stratifications are especially evident in the elevated status Ramabai accords to the 'virtuous' woman, placing her in opposition to prostitutes and servants who she relegates to a 'lowly' level. And her attacks on theatre as public spaces that do not subscribe to the codes of propriety and modesty for women further attest to her puritanical ideas. Additionally, at a time when anticolonial nationalism inspired a revival and idealization of ancient Hindu social customs and laws to recuperate the 'Hindu Golden Age' as a testimony to the fine treatment accorded to Hindu women, Ramabai's biting critique of Manu's social codes for women can be seen as a bold feminist gesture that marks a phenomenal point of intervention in upper-caste 
patriarchal ideologies. Yet despite her defiance of Brahmanical norms regarding marriage, as especially manifested in her choice to marry a non-Brahmin, and her sustained critique of the harsh treatment of Hindu women, especially widows, which she saw as being sanctioned by mainstream Hindu society and its laws and mythology, Ramabai apparently derives her own ideas regarding the proper role for women from Hindu mythology.

In scoping out such complexities, Kosambi also critiques Ramabai's essentialization of the oppressed Indian woman, which, as she argues, remained firmly entrenched within a Western, Orientalist framework. While such a critique is insightful, identifying and elaborating for the readers the particular strands of Orientalist thought that impressed Ramabai would enable a more critical understanding of this complex connection. Such elaboration would also complicate further our reading of Ramabai's views on a variety of subjects pertaining to women and religion, caste politics, women's education, widowhood, Sati and the position of Western women - subjects that were of central importance to colonial and nationalist debates in late 19 th-century India.

In recent years, the issue of translation has also received significant attention in colonial and cultural studies and warrants some commentary in the context of this book. While scholars such as Tejaswini Niranjana have cautioned us to view translations with suspicion, especially colonial translations that became sites for constructing the colonial subjects as inferior, Kosambi's project points to the productive aspects of translation. Not only does it enable an excavation of obscured histories; it also provides us with new information and insights on the contributions made by women such as Ramabai during the Raj. In so doing, projects such as this one serve as social histories of women and their relation to nationalist and colonialist thought. For this reason, Kosambi's translations of Ramabai's essays are a welcome addition to the expanding corpus of recently uncovered and translated stories about and by women such as the late 19th-century actress Binodini Dasi, and housewives such as Rashsundari Devi, whose Amar Jiban has been identified as the first full-scale autobiography in the Bengali language. Overall then, the book makes a significant contribution to translation studies, women's studies, and scholarship exploring the links between culture and colonialism.

doi:10.1057/palgrave.fr. 9400105

\section{Nandi Bhatia}

\section{Old wives' tales: feminist re-visions of film and other fictions}

Tania Modleski; I.B Tauris, London and New York, 1999, £14.95, ISBN 1-86064-386-8 (Pbk)

How women tell stories within patriarchal structures that exclude their voice is a question that feminist scholarship has wrestled with for some time. Recent 